\title{
Alliances, acquisitions and multinational advantage
}

Citation for published version (APA):

Lundan, S. M., \& Hagedoorn, J. (2001). Alliances, acquisitions and multinational advantage. International Journal of the Economics of Business, 8(2), 229-242. https://doi.org/10.1080/13571510110051469

Document status and date:

Published: 01/01/2001

DOI:

10.1080/13571510110051469

Document Version:

Publisher's PDF, also known as Version of record

\section{Please check the document version of this publication:}

- A submitted manuscript is the version of the article upon submission and before peer-review. There can be important differences between the submitted version and the official published version of record.

People interested in the research are advised to contact the author for the final version of the publication, or visit the DOI to the publisher's website.

- The final author version and the galley proof are versions of the publication after peer review.

- The final published version features the final layout of the paper including the volume, issue and page numbers.

Link to publication

\footnotetext{
General rights rights.

- You may freely distribute the URL identifying the publication in the public portal. please follow below link for the End User Agreement:

www.umlib.nl/taverne-license

Take down policy

If you believe that this document breaches copyright please contact us at:

repository@maastrichtuniversity.nl

providing details and we will investigate your claim.
}

Copyright and moral rights for the publications made accessible in the public portal are retained by the authors and/or other copyright owners and it is a condition of accessing publications that users recognise and abide by the legal requirements associated with these

- Users may download and print one copy of any publication from the public portal for the purpose of private study or research.

- You may not further distribute the material or use it for any profit-making activity or commercial gain

If the publication is distributed under the terms of Article $25 \mathrm{fa}$ of the Dutch Copyright Act, indicated by the "Taverne" license above, 


\title{
Alliances, Acquisitions and Multinational Advantage
}

\author{
SARIANNA LUNDAN and JOHN HAGEDOORN
}

\begin{abstract}
This paper reviews recent empirical evidence to assess the implications of alliance formation and increasing merger and acquisition activity of multinationals in the context of the eclectic paradigm. Specifically, the paper will concentrate on the performance implications of international expansion via alliances and mergers, and their relationship to the so-called asset-augmenting foreign direct investment. It has been argued in the literature that the way in which multinationals are able to build on their existing advantages and to add to them by virtue of their international activities confers specific benefits to multinationality. We argue that the growth of cross-border acquisitions and alliances as modalities for international expansion has resulted from the continuing convergence of value-adding capabilities within the Triad, and while such activity can help to augment the asset base of the investing firms, it also has potentially anti-competitive implications.
\end{abstract}

Key words: Alliances; Mergers; Acquisitions; Multinationals; Performance.

FEL classifications: F23, L22, O3.

\section{Introduction}

The aim of this paper is to explore the rise of both strategic partnering activity as well as mergers and acquisitions (M\&As) by multinationals, and to assess to what extent is such activity explained by reference to the OLI paradigm. This paper consists of four main parts: in the first part we begin by briefly reviewing the revisions to the eclectic paradigm and its theoretical underpinnings, with particular focus on the more recent revisions addressing the issue of alliances and the growth in mergers. We then provide an overview of the theoretical literature seeking to explain the rationale for the emergence of the alliance economy and the growth in international acquisitions. In the third part, we will review empirical evidence concerning recent trends in alliance formation as well as mergers and acquisitions in the world economy. In this context, we will also discuss the available evidence on

We thank the editors and two anonymous reviewers for their comments and helpful suggestions. Sarianna Lundan and fohn Hagedoorn are at the University of Maastricht, Faculty of Economics and Business Administration, PO Box 616,6200 MD Maastricht, The Netherlands; e-mail: S.Lundan@mw.unimaas.nl and f.Hagedoorn@mw.unimaas.nl 
the performance implications of both trends, and how they affect our understanding of the benefits of international production.

In the final part, we will discuss the ways in which the concept of ownershipspecific advantage needs to be amended to account for the benefits derived from alliances where no ownership involvement is present. We will also discuss whether it is appropriate, in connection with alliance activity, to discuss the internalisation benefits to the firm, given that externalisation (the market alternative) is often unavailable. Finally, we will discuss the locational variable in light of the growth in mergers and acquisitions as well as alliances to assess whether acquisitions in particular signify the growing importance of location-bound assets.

To counter criticism that the OLI paradigm is a static model of asset exploitation, Dunning (1991) first introduced the dynamics of international production as changes in the OLI configuration of firms over time. While the general concept of changing OLI configurations went some way to introduce dynamism into the paradigm, the increase in alliance and merger activity resulted in the addition of strategic asset-seeking investment as the fourth generic motivation for FDI (Dunning, 1993). Thus in addition to market and resource-seeking investment, we now had efficiency-seeking investment, which sought to improve on the global allocation of resources of the multinational, and strategic asset-seeking investment, which sought to add resources to the firm's present capabilities.

In the two recent assessments of the paradigm (Dunning, 1995, 2000a) there is a clear change in the focus of the argument, where the balance has shifted from the exploitation of ownership advantages abroad to, first, improving the efficiency of the existing configuration of activities and, finally, to the active acquisition of new advantages. While market- or resource-seeking motivations will always characterise some portion of investments, there is an increasing role for the efficiency-seeking and strategic asset-seeking investment, which makes mergers and acquisitions as well as strategic alliances critical to the asset-augmenting FDI undertaken by multinationals. This is accompanied by a renewed interest in the location of production, and in particular in the stickiness of competitiveness-enhancing resources (cf. Dunning, 1998). The predominance of created assets over natural assets has made it possible for economies to converge not only in terms of GNP per capita, but also in terms of their productive structure, while simultaneously it has also created possibilities for the creation of more localised clusters or agglomerations of innovative activity, leading to the emergence of newly desirable locational assets.

\section{Technology and Asset-Seeking Activity}

It is argued here, that the liberalisation of markets and the consequent convergence of productive capabilities within the Triad underlies the ability of multinationals to source abroad not only complementary assets, such as natural resources or cheaper labour, but also technologically intensive assets, similar to the ones they already possess at home. Additionally, it will be argued in the subsequent section, that in many instances the preferred, and possibly the only means of acquiring such assets is either through mergers and acquisitions or by way of strategic alliances.

The fundamental changes in the global economy that have occurred in the past two decades are largely a result of changes that have taken place when the world characterised by competition in static comparative advantages, such as natural resource-based industries typified by the HOS model, is now characterised by the 
accelerating pace of technological change, which induces competition to take place essentially between created factor endowments. The perfect markets of the HOS theory of international trade do not exist, and instead we observe markets with economies of scale, learning-curve economies and oligopolistic competition. Products do not necessarily become technologically stable or standardised in the mature phase of their life cycle, or at least the product is well in its maturity until the pace of technological change surpasses that of the change in the product design itself. In fact, in the modern economy, the mature industries might face severe pressures for a change in technology, and according to Abernathy et al. (1983), a possibility of de-maturity as well.

Technology which contains a large tacit (i.e. non-codified, learning-by-doing) component is non-transferable at arm's length, and hence difficult to imitate (Cantwell, 1991). However, as the technology matures (which need not take very long), it can be reproduced if not in exact replicas, then at least in functional equivalents by competitors, and consequently the monopolistic advantages of the innovating firm are eroded. To thwart this process, the firm needs to re-employ its ownership-specific advantages to produce a continuous stream of new innovations. As Milberg and Gray (1992) have demonstrated, this 'mandated re-investment' requires a steady cash flow for a firm merely to keep up with the competition.

Firms that fail to accumulate the profits necessary to finance such investments experience something akin to the vicious circle of poverty, whereby firms become uncompetitive owing to their inability to invest in $\mathrm{R} \& \mathrm{D}$, and unable to invest in $\mathrm{R} \& \mathrm{D}$ on account of being uncompetitive and squeezed for profits. As Teece (1987, 1992) has suggested, it is necessary for firms to undertake not only investment in $\mathrm{R} \& \mathrm{D}$, but in complementary assets as well to reduce the chances of appropriation by free-riding parties (employees, suppliers, competitors). Still further support for the need of private $R \& D$ is given by Franko (1989) who found that the $R \& D$ intensity of a company, i.e. the proportion of revenues allocated to corporate $R \& D$, was the principal indicator of sales growth performance in relation to its competitors in the 5-10 years following the investment.

Even for firms able to undertake such investments (perhaps through crosssubsidisation within the firm), the magnitude of the expense imposes limits to growth through greenfield investment or acquisition, and increases the attractiveness of joint ventures, minority ownership in subsidiaries and non-equity cooperative alliances as modal choices. (Although the organisational costs arising from a myriad such relationships are not often considered explicitly). ${ }^{1}$ In recent years, the trend has been on one hand for foreign direct investment to be undertaken through (very large) mergers and acquisitions rather than via greenfield investment, while at the same time we have seen a concomitant trend of growth in the numbers of non-equity cross border alliances, particularly in knowledgeintensive sectors (Gomes-Casseres, 1996; Hagedoorn, 1996).

While there are many reasons for firms to take part in various cooperative arrangements, such as risk reduction in oligopolistic competition, or the need to establish a presence in all key markets, many explanations of cooperative behaviour between firms have focused on the benefits derived from tapping into competitors' competencies when the acquisition of such knowledge would be prohibitively expensive through acquisition of full or partial ownership. When considered purely in terms of cash flow constraints, joint ventures (JVs), minority ownership in subsidiaries and non-equity cooperative alliances have become modalities that are more attractive as many globally competitive firms have become squeezed for 
profits. Additionally, when considered from the perspective of the modern 'learning organisation', these relationships, and the network structure of the firm (cf. Thorelli, 1986; Powell, 1990) seem to have many of the benefits of ownership at a substantially reduced cost. ${ }^{2}$

Considerable evidence has been accumulating on the internationalisation of the R\&D activities of multinational firms since the 1980s (for a recent review see the special issue of Research Policy edited by Niosi (1999), as well as Zanfei (2000) and Cantwell and Piscitello (1999, 2000)). It appears that multinationals, particularly in the high-technology sectors, are engaging in asset-augmenting FDI to exploit as well as to build on their home-based competencies, as described by Dunning (1995), Almeida (1996), Dunning and Lundan (1998) and Kummerle (1999). The desire of the multinational to benefit from location-bound 'centres of excellence' is mitigated by its ability to coordinate effectively the flows of knowledge within the organisation. ${ }^{3}$ The research to date has investigated both the agglomeration economies available in particular locations (e.g. Cantwell and Iammarino, 2000; Santangelo, 2000) as well as the patterns of control and coordination within multinationals from a range of home countries (e.g. Pearce, 1999; Zander, 1999).

\section{Patterns of Alliance Formation and Merger Activity}

If alliances and mergers essentially fill the same function in terms of the transfer and acquisition of strategic resources, what accounts for the simultaneous growth in both types of inter-firm relationships? In this section, we will review the existing evidence of the sectoral and geographical distribution of alliance activity, as well as the (more limited) evidence on patterns of mergers and acquisitions. We will also discuss the extent to which the empirical evidence points to similarities or differences in the use of alliances and mergers in the asset-augmenting activity of multinationals. The fact that both mergers and alliances can be used in a similar manner to tap into other firms' knowledge-based assets makes at least some merger and acquisition activity arguably very similar to alliance formation in its motivation.

The overall growth in alliances has been reported in a relatively large number of studies, e.g. Mowery (1988), Mytelka (1991), OECD (1992) and Hagedoorn (1996). Research based on historical data sets, such as the MERIT-CATI databank, reveals that strategic technology alliances have become increasingly popular with firms during the past few decades. Already during the 1960s, researchers from the well-known Harvard Multinational Enterprise project found a number of international joint ventures that undertook substantial joint research projects (Hladik, 1985). At the time, this was rather puzzling for most researchers, since international joint ventures were generally interpreted in the context of market- and resourceseeking activities, which excluded strategic technological assets. However, since the 1970s, we see an almost exponential growth in strategic technology alliances from less than 50 strategic technology alliances founded each year during the mid-1970s, to nearly 600 founded in the 1990s (Hagedoorn, 1996).

During this period of growth in strategic technology alliances, their sectoral distribution appears to have changed as well. The increasing importance of hightechnology sectors, such as pharmaceutical biotechnology, information technology and new materials, has affected the sectoral distribution of strategic technology alliances. Gradually, these 'new' industries have increased their share in strategic 
technology partnering to close to $90 \%$ of all of the alliances established during the 1990s (Hagedoorn, 1996).

A similar concentration of alliance activity is found if one considers the geographical distribution of strategic technology alliances. Freeman and Hagedoorn (1994) report that over 95\% of all strategic technology alliances are formed between companies from the developed economies, suggesting a straightforward relationship between the degree of technological sophistication of an industry and the degree of participation of firms from less developed countries. Not surprisingly, the higher the R\&D intensity of the industry, the lower the participation of companies from developing and emerging economies, as such firms are seldom in possession of knowledge-intensive resources that would be attractive to a Triad partner.

The sectoral and geographical concentration of alliances is testament to the underlying pattern of combining highly tacit capabilities with specific locationbound assets. Research by Hagedoorn and Narula (1996) revealed strategic partnering activity to be more evenly distributed between industrial sectors in more technologically advanced countries (R\&D/GDP greater than 1\%). Subsequent research by Hagedoorn (1996) revealed that certain regions have attracted clusters of international strategic technology partnering activity, such as in the case of the large number of alliances between European pharmaceutical companies and US biotechnology companies, and the many long-term alliances between European information technology companies and semi-conductor and software companies from Silicon Valley. Additionally, although technology partnering is still dominated by the developed economies, there is also some recent evidence that a small group of Asian economies (South Korea, Taiwan, Hong-Kong) are gradually becoming interesting partners for companies from the developed economies, also in terms of their technology-intensive assets, particularly in industries such as electronics and related industries (Duysters and Hagedoorn, 2000).

Although firms of all sizes and different degrees of multinationality engage in strategic alliances, the size of the firm (as measured by the number of employees) was found to be an important factor in explaining the propensity of firms to form alliances (Duysters and Hagedoorn, 1995). Additionally, Hagedoorn (1995) demonstrated that in most industrial sectors, large multinational corporations, mostly those in the Fortune Global 500, are the most active alliance partners. A network analysis of several sectors revealed that many of these multinationals are 'nodal' players in networks of strategic alliances with a variety of alliance partners, with domestic (uninational) firms playing a much more limited role. ${ }^{4}$ Furthermore, the choice of contractual alliances or joint ventures is known to vary by sector, with contractual alliances dominating the high-technology sectors (Osborn and Baughn, 1990), irrespective of the country of origin of either partner (Hagedoorn and Narula, 1996).

As regards the sectoral and geographical patterns of merger and acquisition activity, unfortunately the research to date has focused less on historical patterns, and more on financial performance before and after the merger, as well as on the stock market reaction to merger announcements. Nonetheless, a small number of studies do reveal some general patterns of activity. Overall, it seems that mergers and acquisitions are disproportionately concentrated in sectors other than high technology, where strategic alliances are prevalent. Explanations offered by Ciborra (1991), Oster (1992), Hagedoorn and Sadowski (1999) and Yu and Tang (1992) refer to the need for (organisational) flexibility and the importance of learning, as well as the speed of technological change for alliances in high-tech sectors, whereas 
formal and well-institutionalised modes of control (i.e. mergers and acquisitions) are most appropriate in more stable environments.

Data from the latestWorld Investment Report (UNCTAD, 2000) reveal that crossborder M\&As have accounted for most of the growth in international production over the past decade, even allowing for the differences in the way in which flows of M\&As and greenfield investment are calculated. In total, flows of M\&As accounted for $80 \%$ of all FDI in 1999 . Less than $3 \%$ of mergers and acquisitions are actually mergers, and full acquisitions account for two-thirds of the total, while minority acquisitions are twice as common in the developing countries. Additionally, most cross-border M\&As take place between firms in the same industry, and hostile mergers account for less than $5 \%$ of the total value.

Research by Hagedoorn and Duysters (2002) also indicates that mergers and acquisitions are still frequently preferred to alliances in the context of strategic assetseeking investments related to the organisation's core activities. The extent to which alliances and acquisitions are alike in their strategic motivations is contingent on the question of the extent to which the resources sourced abroad are complementary or similar to the existing competencies of the acquiring firm. While the aggregate evidence doesn't typically reveal the extent to which alliances (or mergers) are undertaken in the core of the company's activities, an analysis by Mowery et al. (1996) of the overlap in patenting activity of US and Japanese alliance partners found that alliances can promote increased specialisation rather than a convergence of capabilities between the partners, and that equity participation promoted greater knowledge transfer. This would suggest that alliances are a preferred means of accessing complementary resources, while equity participation is more effective in more closely related (and stable) fields of activity. Particularly in cases where the acquisition is undertaken to gain the $R \& D$ capabilities of another firm, the primary motivation in both mergers and alliances seems to be the possibility for learning and knowledge transfer, and there is at least some evidence that the creation of a bidirectional flow of information in the context of an acquisition may be more effective than in other forms of inter-firm relationships (see e.g. Bresman et al., 1999).

It is suggested here that a precondition for these mergers is the underlying convergence of productive capabilities within the Triad. If this is correct, we should see high levels of intra-Triad M\&As, whether international or domestic, and few mergers with firms outside of the Triad, particularly in developing countries. Indeed, the aggregate data from UNCTAD (2000) bear this out, as cross-border sales and purchases by firms in the Triad accounted for $82 \%$ and $86 \%$ of the total in 1999. The present boom is also accompanied by a boom in domestic M\&As, particularly within the EU and US. While acquisitions of firms from developing countries have been relatively rare, in 1999 they did account for $10 \%$ of total crossborder sales, boosted by privatisation sales in Latin America and the 'fire sale' of assets after the Asian financial crisis. Furthermore, in Asia, regional investment from Hong Kong, Taiwan and Singapore has also played a role on the acquiring side.

Two reasons for the parallel growth trends are proposed here, namely, the cashflow constraint favouring alliances over acquisitions, and the speed of acquisition coupled with the possibility of more effective communication favouring acquisitions. Another reason for the simultaneous increase might be that alliances act as an introductory stage to eventual mergers and acquisitions. However, evidence from Hagedoorn and Sadowski (1999) indicates that alliances are not a gateway to 
mergers, since out of the nearly 13,000 instances of alliance formation in the MERIT-CATI database (which focuses exclusively on technological cooperation) only $2.6 \%$ were converted into mergers over a 3-year period. According to their evidence, not only are conversions from alliances to mergers rare, but they appear to be seemingly random, as neither size nor country of origin had a significant impact on the rate of conversion. We can thus conclude that while alliances and acquisitions are distinct forms of inter-firm partnering, they are often undertaken with the same motivation of adding to a firm's stock of knowledge-intensive assets.

In the World Investment Report (UNCTAD, 2000) an analogy is made between the merger wave in the USA 100 years ago, and the present situation in the world economy, where high levels of technological and regulatory change are present. Then as now, there is an aspect of consolidation as well as asset acquisition underlying the desire to merge, prompted by rapid changes in the environment. If the primary aim of a merger is the elimination of competition, the degree of convergence of the underlying assets is of lesser consequence, and the availability of financing as well as the degree of effective anti-trust legislation will act as constraints on merger activity. If, on the other hand, the acquisition of assets, and in particular knowledge-intensive assets, is the primary motivation for the merger, the productive assets of both firms have to be similar enough for effective absorption to take place.

There is also something of a time dimension to our argument, which suggests a progression from a wave of domestic mergers to initial FDI via greenfield (fully or majority-owned) investment, to be followed by joint ventures and minority investments, and culminating in knowledge-seeking mergers and strategic alliances in an integrated global economy. While it is beyond the scope of this paper to offer conclusive evidence of this dynamic, a few examples can be given. The consolidation of US and British industry by the early 1900s was followed by market- and resourceseeking (greenfield) investment before World War II. ${ }^{5}$ In the post-war era, evidence from Gomes-Casseres (1988) for 1945-1975 indicates a period of boom for joint venture activity peaking in 1961, followed by a decline in joint ventures in restricted as well as unrestricted markets. If the interest shown in academic journals is anything to go by, joint ventures seem to have been surpassed in importance by alliances as we get to the mid-1980s, and we have already documented the rise of merger and alliance activity in the past 20 years. While joint ventures still take place, particularly in (developing) countries where this form of investment can be required or encouraged, cooperative activity is now equally likely to take place either as a non-equity strategic alliance, or a minority stake in another firm.

To the extent that entry restrictions rather than the lack of knowledge about a foreign market were an important reason for the emergence of joint ventures, as such restrictions fade, joint ventures might come to represent a largely transitional form of foreign ownership. Compared to the 'pure' modalities of non-equity alliances and mergers, joint ventures are a half-way house involving some control and some cooperation. Following the Buckley and Casson (1988) argument for deciding on the merits of a cooperative form of business, the joint venture modality seems to be inferior to both mergers and alliances. While a full merger naturally exploits the benefits of full control, but comes at a price, a minority stake can buy some access and influence as well as a share of any profit, without the complications of starting a new venture. On the other hand, a non-equity alliance offers the full benefit of cooperation without the burdens (or benefits) of control and ownership, 
which in the case of technology cooperation is thought to be antithetical to its purpose in any case.

\section{Re-examining the OLI-Variables}

Increasing knowledge-seeking cross-border activity in the form of M\&As and alliances has necessitated a modification of the eclectic paradigm to emphasise the distinction between asset-exploiting and asset-seeking activities. While there remains an important role for market- and resource-seeking investment, such as in the case of China, for example, convergence of productive capabilities within the Triad has created possibilities for firms not only to exploit their ownership advantages abroad but also to absorb productive capabilities and to incorporate them into their network of activities. There are two main ways in which the merger (and alliance) activity of multinationals could affect their profitability; either by increasing industry concentration and generating oligopolistic profits, as originally envisaged by Hymer (1976), or by allowing the firm access to location-bound knowledge resources and thus upgrading its competitive capabilities. In the following sections we will examine how each of the OLI variables is affected by the growth in cooperative relationships and increased merger activity.

\subsection{Ownership-Specific Advantages}

Although to an extent it is a matter of definition, we agree with Dunning (1995) that the asset-related ownership-specific advantages are not likely to change, at least in the short run, as a result of co-operative behaviour by firms. However, looking at asset-related ownership advantages (Oa) from the point of view of absorption rather than dissemination, they form the basis on which other firms choose to collaborate with the multinational, and are also a measure of its attractiveness as a partner.

We argued in the previous section that the choice of how to access the resources or capabilities of another firm depends on number of factors. The cash flow implications of an acquisition as opposed to a contractual alliance would favour the latter in uncertain environments such as in the high-technology sectors, where the need to partner with a large number of firms is apparent. We also argued that mergers might be preferred in areas of activity that are closer to the core activities of the firm owing to the greater ability of the firm to integrate these activities within the firm.

The transaction-related advantages (Ot) of the multinational can be thought of as the benefits of multinationality per se, and they will increase in magnitude with increasing internationalisation. Some of these benefits arise out of the ability of the multinational to efficiently coordinate its activities across borders, which increasingly also involves the ability to coordinate activities between firms. Particularly in cooperative relationships, such managerial capabilities are inherently valuable. To the extent that (large) multinational firms are likely to have better access to managerial capabilities, and are likely to be in a position to partner with other firms globally, multinationality itself will confer benefits over and above those enjoyed by uninational firms.

In a recent contribution Dunning (2000b) has addressed the issues of regeneration and exploitation of ownership assets with reference to relational assets that are owned or accessed by a firm, and defined as a 'willingness and capability to access, shape and engage in economically beneficial relationships ... [that] take 
place both within the confines of a particular firm or between that firm and other organisations'. While this definition covers all of the modalities of international business, relational capabilities are particularly salient in the case of M\&As and alliances, where the firm's ability to manage its boundary is critical. In the case of mergers (acquisitions), this involves the creation of a new entity with a new culture, or more commonly, the inculcation of the dominant culture in an enlarged organisation. In the case of joint ventures, a new entity is created, making it similar to the merger case, but it also shares with contractual agreements the problem of having to rely on trust to manage beyond the scope of inherently incomplete contracts.

In all three instances, the ultimate financial outcome seems to hinge on the ability of the multinational to coax cooperation out of essentially reticent outsiders. The literature is replete with examples of organisations that inculcate values of trust and cooperation to their members, ranging from criminal networks like the mafia, to business networks like those of the overseas Chinese, or indeed the bonds between family members. In each case, cooperation from within is expected, while cooperation from the outside needs to be gained through persuasion or coercion. While mergers and acquisitions offer more opportunities for coercion than joint ventures or alliances, if the marriage-metaphor of cooperative activity (e.g. Kanter, 1994 ) is to be believed, the firms that successfully manage their relational assets are more likely to persuade than to coerce. In the end, successful persuasion works by bringing the outsiders inside, since the more the partners share common values and beliefs about the purpose of their collaboration, the more likely it is that they will act in ways that benefit the partnership rather than the individual firm.

\subsection{Location}

The sourcing of technologically intensive assets is linked to the increasing importance of locationally specific assets in areas such as Silicon Valley in California or Silicon Glen in Scotland, where a specialised industry generates externalities in information exchange and the creation of new knowledge. Research on the institutional context supporting such areas, as well as on the effects of spillovers and agglomeration economies of firms investing in a given area is substantial and growing (e.g. Cantwell and Iammarino, 1998; Dunning, 2000; Cantwell and Noonan, 2001). To the extent that such externalities are specific to an area, they offer a unique location-bound resource that can only be utilised by a local or multinational firm. The access to such assets, whether possessed by other firms, government sponsored research programmes, or university-linked institutions, represents a resource for which no external market exists. Consequently, such assets are liable to be sourced by a means either involving ownership, as in the case of mergers and acquisitions, or non-equity linkages as in the case of strategic alliances.

The access to specific geographically dispersed resources can be taken to be a benefit of multinationality, although at its core, it is a benefit of mobility (and size), with multinationality being the consequence of the underlying geographical distribution of such location-bound assets. Thus, for example, an American firm investing in Silicon Valley is not reaping the benefits of multinationality, and neither is an English firm investing in Silicon Glen, unless the devolution of Scotland results in its separation from the UK, while clearly the profit-enhancing possibilities are the same for them as they are for a French firm in either location. 


\subsection{Internalisation}

The internalisation advantage in connection with the absorption of knowledge and capabilities from abroad is a bit of a misnomer, as many such relationships are characterised by a minimal or entirely absent equity involvement. However, the organisation of such relationships in a quasi hierarchy can provide benefits to the firm beyond what is available in the marketplace. ${ }^{6}$ The critical constraint in this context is the net cost, so that while in some cases an acquisition or merger might be the preferred modality, the use of cooperative arrangements within a quasi hierarchy can yield similar benefits at a lower cost.

The advantages of close relationships can be better understood in terms of the economies of common governance, i.e. in terms of the efficiencies and cost savings obtained by working within a hierarchy. Drawing on Casson (1986) and Williamson (1979), Gray and Lundan (1993) compiled five conditions in which a hierarchy might contribute to internalisation efficiencies in vertical production and horizontal marketing and distribution relationships; their list has been amended here to fit a more general context:

(1) the activity between units is large and recurring;

(2) there exist uncertainties with respect to price, quantity and design of the product or process sought;

(3) product-specific equipment will reduce costs but will expose both parties in an arm's length relationship to an unequal share of losses or gains when product design and process technologies change within the life of the activityidiosyncratic capital equipment;

(4) tight quality standards are imposed by the purchaser (the assumption here is that costs of quality control are an increasing function of quality standards for both firms or units so that elimination of one round of quality control will engender greater cost savings);

(5) when one party owns production relevant proprietary expertise so that the appropriability is increased by an internal transfer.

While all five conditions would favour the choice of hierarchy over market, or the internalisation of the transaction, the prohibitively high cost of internalising all such transactions has led firms to pursue other solutions. The rise of quasi-hierarchical governance structures can thus be seen in the emergence of network arrangements between corporations, particularly in the research and development area. Multinational corporations have increasingly come to realise, that to overcome the market failure associated with $\mathrm{R} \& \mathrm{D}$ activities, a reciprocal arrangement between corporations with no equity involvement and no formal (long-term) contractual relationship will spread the costs and enable the MNE to take on R\&D that otherwise would not be feasible.

However, the creation of corporate networks in the form of strategic alliances and (non-equity) partnerships entails costs to the participants separate from those ordinarily experienced in the marketplace or those induced by the government. Powell (1990) points out at least two such costs for participating MNEs in a network configuration. First, as networks are based on a reciprocal pattern of communication and exchange, the preferred option for participants is often one of creating indebtedness and reliance over the long haul to reduce uncertainty of termination of participation in the network. Second, dependence and particularism in member selection are characteristics that serve to restrict access to the network 
after the initial formation. As the costs of monitoring network activities can be substantial, stability and trust in the network setup becomes a critical management challenge.

\section{Conclusions}

In this paper, we have reviewed recent evidence of the growth in alliances and acquisitions and analysed their effects in terms of the OLI paradigm. We present evidence indicative of a changing dynamic, whereby multinationals (within the Triad) are moving from the dissemination and exploitation of ownership advantages to the attraction and absorption of competitive advantages abroad. These changes can be accommodated within the OLI paradigm, by making explicit the two-way flow of resources, and effectively creating a mirror image of the original variables. The eclectic paradigm can thus explain not only the ability of the multinational to exploit its advantages abroad, but it can also be used to describe the essential elements that would allow the multinational to access and acquire advantages abroad to sustain long-term growth.

We suggest (without being able to offer conclusive evidence) a progression from domestic mergers to initial foreign production via greenfield investment, to be followed by joint ventures and minority investments, and culminating in knowledgeseeking mergers and strategic alliances. This dynamic is made possible by the increasing convergence of the underlying knowledge-based assets as a result of globalisation, enabling firms ultimately to undertake cross-border cooperative activity either in the form of mergers, minority ownership or through strategic alliances. The primary benefits of multinationality potentially linked to profitability are argued to be the ability of the multinational to combine mobile investment with location-bound assets, as well the pool of talent available to the multinational to manage such assets. However, increasing global industry concentration as a result of the growth in cross-border mergers also evokes old concerns about the true advantage of multinationality lying in oligopolistic profits.

The patterns of partnering activity present a picture of concentration, both in terms of a sectoral concentration in high technology, as well as a geographical concentration within the Triad. However, underneath the aggregate patterns lie two trends worth noting: the persistence of contractual agreements to acquire and develop knowledge intensive assets; and the trend of internationalisation of the $R \& D$ activities of the multinational. The persistence of contractual R\&D agreements can be seen as evidence of the development of a new type of transactionrelated ownership advantage by multinationals related to knowledge acquisition. The internationalisation of the $\mathrm{R} \& \mathrm{D}$ function is partly related to new ways of developing knowledge within the firm (and between firms), but it is also related to tapping into location-bound sources of expertise found abroad. Both (non-equity) alliances as well as acquisitions can be used to develop and acquire new resources, and warrant a closer examination as related activities in the value creation process of multinationals.

\section{Notes}

1. For example, Arrow (1974) focused on how the concentration of information at the top of the organisation both helps to economise on information while also setting limits to its effective dissemination. 
2. It should be noted, that we are discussing two types of networks: a hybrid type of firm that combines elements of hierarchy and market (quasi hierarchy), and network as the pattern of (voluntary) connections between participants, e.g. at a research consortium.

3. See also Holm and Pedersen (2000).

4. See also D'Cruz and Rugman (1993) on the role of the multinational as a flagship firm.

5. We are indebted to an anonymous reviewer for pointing out that mergers in one period and alliances in another did not necessarily take place in the same industries.

6. Even if information asymmetry or contractual difficulties make it unlikely that some types of information will be exchanged over the market, the market for corporate control still exists, and can be used at least in principle to acquire such benefits.

\section{References}

Abernathy, W.J., Clark, K.B. and Kantrow, A.M., Industrial Renaissance - Producing a Competitive Future for America. New York: Basic Books, 1983.

Almeida, P., "Knowledge Sourcing by Foreign Multinationals: Patent Citation Analysis in the U.S. Semiconductor Industry," Strategic Management fournal, 1996, 17, pp. 155-65.

Arrow, K., The Limits of Organization. New York: Norton, 1974.

Bresman, H., Birkinshaw, J. and Nobel, R., "Knowledge Transfer in International Acquisitions," fournal of International Business Studies, 1999, 30(3), pp. 439-462.

Buckley, P. and Casson, M., "A Theory of Cooperation in International Business," in F. J. Contractor and P. Lorange, eds, Cooperative Strategies in International Business. Lexington, Mass.: Lexington Books, 1988.

Cantwell, J.A., "The Theory of Technological Competence and Its Application to International Production," in D. G. McFetridge, ed., Foreign Investment, Technology and Economic Growth. Calgary: University of Calgary Press, 1991.

Cantwell, J. and Iammarino, S., "MNCs, Technological Innovation and Regional Systems in the EU: Some Evidence in the Italian Case," International fournal of the Economics of Business, 1998, 5(3) pp. 383-408.

Cantwell, J. and Piscitello, L., "Accumulating Technological Competence: Its Changing Impact on Corporate Diversification and Internationalization," Industrial and Corporate Change, 2000, 9(1), pp. 21-51.

Cantwell, J. and Iammarino, S., "Multinational Corporations and the Location of Technological Innovation in the UK Regions," Regional Studies, 2000, 34, pp. 317-32.

Cantwell, J. and Noonan, C.A., "The Regional Distribution of Technological Development - Evidence from Foreign-Owned Firms in Germany," in M. P. Feldman and N. Massard, eds, Knowledge Spillovers and the Geography of Innovation. Dordrecht: Kluwer, 2001, forthcoming.

Cantwell, J.A. and Piscitello, L., "The Emergence of Corporate International Networks for the Accumulation of Dispersed Technological Competencies," Management International Review, 1999, 39, pp. $123-47$.

Casson, M.C., Multinationals and World Trade. London: Allen and Unwin, 1986.

Ciborra, C., "Alliances as Learning Experiments: Cooperation, Competition and Change in High-Tech Industries,” in L. K. Mytelka, ed., Strategic Partnerships and theWorld Economy. London: Pinter, 1991, pp. 51-77.

D'Cruz, J.R. and Rugman, A.M., "Developing International Competitiveness: The Five Partners Model," Ivey Business Quarterly, 1993, 58(2), pp. 60-72.

Dunning, J.H., "The Eclectic Paradigm of International Production: A Personal Perspective," in C. N. Pitelis and R. Sugden, eds, The Nature of the Transnational Firm: London: Routledge, 1991.

Dunning, J.H., Multinational Enterprises and the Global Economy. Wokingham, Berkshire: Addison Wesley, 1993.

Dunning, J.H., "Reappraising the Eclectic Paradigm in the Age of Alliance Capitalism," fournal of International Business Studies, 1995, 26(3), pp. 461-91.

Dunning, J.H., "Location and the Multinational Enterprise: A Neglected Factor?," fournal of International Business Studies, 1998, 29(1), pp. 45-66.

Dunning, J.H., "The Eclectic Paradigm as an Envelope for Economic and Business Theories of Mne Activity," International Business Review, 2000a, 9, pp. 163-190.

Dunning, J.H. "Relational Assets, Networks and International Business Activity.” Paper presented at the European International Business Academy, Maastricht, 2000b. 
Dunning, J.H., ed., Regions, Globalization and the Knowledge-Based Economy. Oxford: Oxford University Press, 2000c.

Dunning, J.H. and Lundan, S.M., "The Geographical Sources of Competitiveness of Firms: An Econometric Analysis,” International Business Review, 1998, 7(2), pp. 115-133.

Duysters, G. and Hagedoorn, J. "Strategic Groups and Inter-Firm Networks in International High-Tech Industries," fournal of Management Studies, 1995, 32, pp. 361-81.

Duysters, G. and Hagedoorn, J. "International Technological Collaboration: Implications for Nies," in L. Kim and R. R. Nelson, eds, Technological Learning and Economic Development: The Experience of the Asian Newly Industrialized Countries. Cambridge: Cambridge University Press, 2000, pp. 193-215.

Franko, L.G., "Global Corporate Competition: Who"s Winning Who"s Losing and the R\&D Factor as One Reason Why," Strategic Management fournal, 1989, 10, pp. 449-474.

Freeman, C. and Hagedoorn, J., "Catching up or Falling Behind: Patterns in International Interfirm Partnering," World Development, 1994, 22, pp. 771-780.

Gomes-Casseres, B., "Joint Venture Cycles: The Evolution of Ownership Strategies of U.S. MNEs, 1945-75," in F.J. Contractor and P. Lorange, eds, Cooperative Strategies in International Business. Lexington, MA: Lexington Books, 1988.

Gomes-Casseres, B., The Alliance Revolution: The New Shape of Business Rivalry. Cambridge, MA: Harvard University Press, 1996.

Gray, H.P. and Lundan, S., "The Importance of Intra-Firm Trade," in M.E. Kreinin, ed., The Political Economy of International Commercial Policy: Issues for the 1990s. London: Taylor \& Francis, 1993.

Hagedoorn, J., "A Note on International Market Leaders and Networks of Strategic Technology Partnering," Strategic Management fournal, 1995, 16, pp. 241-250.

Hagedoorn, J., "Trends and Patterns in Strategic Technology Partnering since the Early Seventies," Review of Industrial Organization, 1996, 11(5), pp. 601-16.

Hagedoorn, J. and Narula, R. "Choosing Organizational Modes of Strategic Technology Partnering: International and Sectoral Differences," fournal of International Business Studies, 1996, 27(2), pp. $265-84$.

Hagedoorn, J. and Sadowski, B., "The Transition from Strategic Technology Alliances to Mergers and Acquisitions: An Exploratory Study," fournal of Management Studies, 1999, 36, pp. 87-107.

Hagedoorn, J. and Duysters, G.,"External Sources of Innovative Capabilities: The Preference for Strategic Alliances or M\&As," Fournal of Management Studies, 2002, forthcoming.

Hladik, K.J., International foint Ventures. Lexington, MA: Lexington Books, 1985.

Holm, U. and Pedersen, T., eds, The Emergence and Impact of MNC Centers of Excellence. Basingstoke: Macmillan, 2000.

Hymer, S.H., The International Operations of National Firms. Lexington, MA: Lexington Books, 1976.

Kanter, R.M., "Collaborative Advantage: The Art of Alliances," Harvard Business Review, 1994, (JulyAugust), pp. 96-108.

Kummerle, W., "The Drivers of Foreign Direct Investment into Research and Development: An Empirical Investigation,” Fournal of International Business Studies, 1999, 30(1), pp. 1-24.

Milberg, W.S. and Gray, H.P., "International Competitiveness and Policy in Dynamic Industries," Banca Nazionale del Lavoro Quarterly Review, March, 1992, 180, pp. 59-80.

Mowery, D., Oxley, J.E. and Silverman, B.S., "Strategic Alliances and Interfirm Knowledge Transfer," Strategic Management fournal, 1996, 17, pp. 77-91.

Mowery, D.C., ed., International Collaborative Ventures in U.S. Manufacturing. Cambridge: Ballinger, 1988.

Mytelka, L.K., Strategic Partnerships and the World Economy. London: Pinter, 1991.

Niosi, J., "The Internationalization of Industrial R\&D: From Technology Transfer to the Learning Organization," Research Policy, 1999, 28 (2-3), pp. 107-17.

OECD., Technology and the Economy. Paris: OECD, 1992.

Osborn, R.N. and Baughn, C.C. "Forms of Interorganizational Governance for Multinational Alliances," Academy of Management fournal, 1990, 33(3), pp. 503-19.

Oster, S.M., Modern Competitive Analysis. New York: Oxford University Press, 1992.

Pearce, R.D., "Decentralised R\&D and Strategic Competitiveness: Globalised Approaches to Generation and Use of Technology in Multinational Enterprises (MNEs)," Research Policy, 1999, 28(2-3), pp. 157-78.

Powell, W.W., "Neither Market nor Hierarchy: Network Forms of Organization," Research in Organizational Behavior, 1990, 12, pp. 295-336.

Santangelo, G.D., "Inter-European Regional Dispersion of Corporate Research Activity in Information and Communications Technology: The Case of German, Italian and UK Regions," International fournal of the Economics of Business, 2000, 7(3), pp. 275-95. 
Teece, D., "Strategies for Capturing the Financial Benefits from Technological Innovation," in N. Rosenberg, R. Landau and D. C. Mowery, eds, Technology and the Wealth of Nations. Stanford: Stanford University Press, 1992.

Teece, D.J., The Competitive Challenge - Strategies for Industrial Innovation and Renewal. New York: Harper \& Row, 1987.

Thorelli, H.B., "Networks: Between Markets and Hierarchies,” Strategic Management fournal, 1986, 7, pp. 37-51.

UNCTAD, World Investment Report 2000: Mergers and Acquisitions. New York and Geneva: United Nations, 2000.

Williamson, O., "Transaction Cost Economics: The Governance of Contractual Relations," fournal of Law and Economics, 1979, 22, pp. 236-61.

Yu, C.-M.J. and Tang, M.-J. “International Joint Ventures: Theoretical Considerations,” Managerial and Decision Economics, 1992, 13, pp. 331-42.

Zander, I., "How Do You Mean "Global"? An Empirical Investigation of Innovation Networks in the Multinational Corporation," Research Policy, 1999, 28(2-3), pp. 195-213.

Zanfei, A., "Transnational Firms and the Changing Organisation of Innovative Activities," Cambridge fournal of Economics, 2000, 24, pp. 515-42. 
Copyright of International Journal of the Economics of Business is the property of Journals Oxford Ltd. and its content may not be copied or emailed to multiple sites or posted to a listserv without the copyright holder's express written permission. However, users may print, download, or email articles for individual use. 